Jurnal Bimbingan dan Konseling Ar-Rahman
Volume 7, Nomor 2, Tahun 2021
Tersedia Online: http://ojs.uniska.ac.id/index.php/BKA
e-ISSN 2477-6300

\title{
HUBUNGAN POLA ASUH ORANG TUA DENGAN TINGKAT KEDISIPLINAN SISWA SMP NEGERI 15 KOTA KUPANG DI MASA PANDEMI COVID 19
}

\author{
Petrisia Anas Waluwandja, Sanhedri Boimau, Dixon E.M. Taek Bete \\ Universitas Persatuan Guru 1945, Nusa Tenggara Timur \\ hetris123@gmail.com
}

\begin{abstract}
ABSTRAK
Hasil belajar siswa mulai menurun di masa pandemi COVID-19. Penelitian ini bertujuan mengetahui hubungan pola asuh orang tua dengan tingkat kedisiplinan siswa SMP Negeri 15 Kota Kupang pada masa Pandemi Covid 19. Penelitian ini menggunakan pendekatan korelasi. Sampel dalam penelitian ini berjumlah 60 orang siswa. Hasil penelitian menunjukkan bahwa : (1) Pola asuh orang tua siswa SMP Negeri 15 Kota Kupang dengan nilai rata-rata sebesar 83, 98 termasuk kedalam kategori cukup baik yaitu berada pada interval 81-85; (2) Tingkat kedisiplinan siswa SMP Negeri 15 Kota Kupang dengan nilai rata-rata sebesar 82,11 dikategorikan cukup baik yaitu berada pada interval 78-83; (3) Hasil analisis hipotesis menunjukkan bahwa nilair $x y=0,526$ berada pada arah yang positif. Hubungan pola asuh orang tua dengan tingkat kedisiplinan siswa SMP Negeri 15 Kota Kupang termasuk dalam kategori cukupkuat dengan interval 0,40-0,599; (4) Data penelitian dan hasil juga menunjukkan bahwa $\mathrm{t}_{\text {hitung }}=0,526$, sedangkan $\mathrm{t}_{\text {tabel }}$ pada taraf signifikansi $5 \%=1,671$ dan $t$ tabel pada taraf signifikan $1 \%=2,390$. Ini berarti bahwa $\mathrm{t}_{\text {hitung }}$ lebih besar dari $t_{\text {tabel }}$. Maka dapat disimpulkan bahwa ada hubungan yang signifikan antara pola asuh orang tua dengan tingkat kedisiplinan siswa kelas SMP Negeri 15 Kota Kupang.
\end{abstract}

Kata Kunci: Pola; Asuh; Kedisiplinan; Pandemi; Covid

\begin{abstract}
Student's learning outcomes began to decline during the COVID-19 pandemic. This study aims to determine the relationship between parenting patterns and the level of discipline of students at SMP Negeri 15 Kupang City during the Covid 19 Pandemic. This study applies a correlation approach. The number of samples in this study are 60 students. The results showed that: (1) The parenting pattern of the students of SMP Negeri 15 Kupang City with an average score of 83, 98 was included in the fairly good category, which was in the 81-85 interval; (2) The level of discipline of students of SMP Negeri 15 Kupang City with an average score of 82.11 is categorized as quite good, which is in the 78-83 interval; (3) The results of the hypothesis analysis show that the value of rxy $=0.526$ is in a positive direction. The relationship between parenting patterns and the level of discipline of students at SMP Negeri 15 Kupang City is included in the fairly strong category with an interval of 0.40-0.599; (4) The research data and results also show that tcount $=0,526$, while ttable at a significance level of 5\% =1,671 and table at a significant level of $1 \%=2,390$. This means that tcount is greater than ttable. So it can be concluded that there is a significant relationship between parenting patterns and the level of discipline of students of SMP Negeri 15 Kupang City.
\end{abstract}

Keywords: Pattern; parrenting; Discipline; Pandemic; Covid 


\section{PENDAHULUAN}

Pendidikan adalah hal yang penting bagi kehidupan manusia. Melalui proses pendididkan manusia dapat hidup berkembang sejalan dengan aspirasi (cita-cita) untuk maju, sejahtera dan bahagia menurut konsep pandangan hidup mereka (Donald, 2014). Pendidikan, dalam arti yang digunakan di sini, adalah proses atau kegiatan yang diarahkan untuk menghasilkan perubahan yang diinginkan dalam perilaku manusia. Pendidikan menjadikan seseorang lebih bertaqwa kepada Tuhan Yang Maha Esa, memiliki pengetahuan, keterampilan dan kepribadian yang akan mengembangkan potensi diri.

Dilihat dari segi struktural, pendidikan yang pertama yang diterima oleh anak adalah pendidikan keluarga. Pendidikan keluarga merupakan lingkungan pertama bagi anak mendapat pengaruh sadar. Sedangkan kalau dilihat dari operasionalnya, pendidikan keluarga merupakan pendorong dan pemberi semangat bagi anaknya (Ishan, 2016). Selajan dengan itu, Armico, (2014) menyatakan bahwa pendidikan keluarga merupakan kelompok sosial terkecil dan paling penting di masyarakat, karena dalam proses pembentukan dan pembinaan kepribadian anak, terlebih dalam penanaman nilai religius dan dewasa secara jasmani dan rohani akan sehat ketika keluarganya mendapat perhatian bimbingan dan kasih sayang dari orangtua. Orangtua merupakan salah satu unsur yang memegang peran penting dalam ranah pendidikan untuk mengasuh mendidik anaknya di rumah (Musaheri, 2013).

Selain dari orang tua, Guru juga merupakan salah satu elemen terpenting dalam lembaga pendidikan (sekolah). Sekolah hendaknya dapat diusahakan menjadi lapangan yang baik bagi pertumbuhan dan perkembangan mental dan moral anak didik. Namun dalam kenyataannya terkadang guru tidak dapat mengatasi anak didiknya di sekolah. Berhasil dan tidaknya peserta didik tergantung pola asuh yang diberikan oleh guru di sekolah dan orangtua di rumah.

Pola asuh atau mengasuh anak adalah semua aktivitas orang tua yang berkaitan dengan pertumbuhan fisik dan otak. Apabila pola asuh orang tua yang diberikan orangtua kepada anak salah maka akan berdampak pada kepribadian anak itu sendiri (Syaiful, 2014). Orang tua selalu mempunyai pengaruh yang paling kuat pada anak-anak. Setiap orang tua mempunyai gaya tersendiri dalam hubungannya dengan anak- anaknya, dan ini mempengaruhi perkembangan sosial anak.

Menurut Handika dan Fadhilaturrahmi (2020) mengatakan bahwa rendahnya perilaku prososial siswa tingkat sekolah dasar di SDN 001 Airtiris yang diduga oleh berbagai faktor seperti pola asuh yang diberikan oleh orang tua di rumah terhadap anak.

Dengan munculnya pandemi di tahun 2019 sampai sekarang, sangat mempengaruhi hasil belajar siswa. Hal tersebut disebabkan oleh rendahnya disiplin siswa serta kurangnya perhatian orang tua (Herliandry, (2020:36). Disiplin merupakan upaya untuk membuat anak berada pada jalur sikap dan perilaku yang sudah ditetapkan pada individu oleh orangtua. Kedisiplinan ini diajarkan oleh orangtua sejak dini, hal ini dimaksudkan agar anak terbiasa dengan hidup teratur, karena hal ini juga akan berdampak positif bagi kehidupan di masa yang akan datang. Pola asuh disiplin merupakan suatu proses bimbingan yang bertujuan untuk menanamkan pola perilaku tertentu, kebiasaankebiasaan tertentu, untuk meningkatkan kualitas dirinya (Shochib, 2014:11). Hal tersebut selaras dengan pandangan Estima, (dkk. 2019) bahwa kedisiplinan dalam segala hal menjadi salah satu faktor penentu keberhasilan seseorang. Untuk membentuk manusia yang disiplin membutuhkan waktu dan proses. Harus ada penerapan sejak dini agar seseorang terbiasa melakukan hal-hal secara teratur dan terjadwal. Oleh karena itu menerapkan kedisiplinan melalui pola asuh orang tua sejak dini pada anak sangat penting untuk dilakukan, karena pada masa anak-anak pembentukan kedisiplinan masih mudah untuk diterapkan. Salah satu upaya yang dapat dilakukan adalah mengundang anak-anak untuk mengaktifkan diri dengan nilai-nilai moral yang dimiliki dan mengembangkan dasar-dasar disiplin diri. Dengan demikian, upaya tersebut menunjukkan perlu adanya posisi dan tanggungjawab dari orang tua. Karena orang tua berkewajiban meletakkan dasar-dasar disiplin kepada anak, serta dapat mengembangkan disiplin diri bersama sekolah dan masyarakat.

Disiplin merupakan upaya untuk membuat anak berada pada jalur sikap dan perilaku yang sudah ditetapkan pada individu oleh orangtua. Kedisiplinan ini diajarkan oleh orangtua sejak dini, hal ini dimaksudkan agar anak terbiasa dengan hidup teratur, karena hal ini juga akan berdampak positif bagi kehidupan dimasa yang akan datang. Pendidikan disiplin merupakan suatu proses bimbingan yang bertujuan untuk menanamkan pola 
Petrisia Anas Waluwandja, Sanhedri Boimau, Dixon E.M. Taek Bete

Jurnal Bimbingan dan Konseling Ar-Rahman

Volume 7, Nomor 2, Tahun 2021

e-ISSN 2477-6300

perilaku tertentu, kebiasaan-kebiasaan tertentu, untuk meningkatkan kualitas dirinya.

Selanjutnya Wiyani, (2013:14) menyatakan bahwa Pembentukan karakter disiplin pada anak usia dini merupakan titik awal menuju pembentukan generasi unggul yang berkualitas, memiliki kepribadian yang baik serta bertanggung jawab. Karakter disiplin memudahkan anak usia dini untuk dapat mengontrol diri dan berinteraksi sosial serta diterima oleh masyarakat. Bentuk pengendalian diri terhadap perilaku anak usia dini dapat berupa sikap taat dan patuh terhadap aturan yang berlaku, baik di rumah, sekolah, maupun masyarakat yang dilakukan oleh anak usia 0-6 tahun.

Hal ini sejalan dengan pendapat Dian Mayasari, dkk. (2021:12) bahwa Untuk melatih kedisiplinan anak, guru dan orang tua dituntut untuk dapat memberikan bimbingan dan pengarahan serta memberikan contoh atau model yang baik bagi anak. Anak usia dini memiliki karakteristik meniru dimana anak mulai peka dan sensitif terhadap rangsangan yang ada disekitarnya termasuk segala yang dilakukan orang tua. Masa peka merupakan masa terjadinya kematangan fungsi fisik dan psikis yang siap merepson stimulasi yang diberikan oleh lingkungan. Oleh sebab itu orang tua dapat menjadi role model disiplin untuk anak.

Menurut observasi terbatas yang dilakukan peneliti dapat disimpulkan bahwa menurunya prestasi peserta didik tergantung pola asuh baik dari orangtua maupun guru khsusnya di SMP Negeri Kota Kupang, hal inilah yang yang membuat peneliti ini mengetahui mengetahui hubungan pola asuh orang tua dengan tingkat kedisiplinan siswa SMP Negeri 15 Kota Kupang pada masa Pandemi Covid 19.

Berbagai upaya dilakukan pemerintah untuk memutus mata rantai penyebaran virus ini, di antaranya pembatasan sosial berskala besar dalam rangka percepatan penanganan Covid-19 yang berakibat pada pembatasan berbagai aktivitas termasuk di antaranya sekolah. Sementara itu aktivitas belajar dari rumah (BDR) secara resmi di keluarkan melalui Surat Edaran Menteri Pendidikan dan Kebudayaan Nomor 36962/MPK.A/HK/2020 tentang pembelajaran secara daring dan bekerja dari rumah dalam rangka pencegahan penyebaran corona virus disease (COVID- 19). Semua pihak baik itu peserta didik, pendidik, dan orang tua menghadapi dan menjalani kehidupan yang baru melalui berbagai pendekatan, strategi maupun metode pembelajaran. Salah satunya menggunakan media digital (whatsapps, google meeting maupun zoom) supaya pembelajaran dapat terus berlangsung (Dian Mayasari, dkk. 2021:10).

\section{METODE}

Jenis penelitian ini adalah penelitian kuantitatif dengan menggunakan pendekatan korelasional yaitu suatu penelitian yang melibatkan tindakan pengumpulan data guna menentukan apakah ada hubungan dan tingkat hubungan antara dua variabel. Variabel yang akan diukur koefisien korelasinya dalam penelitian ini yaitu pola asuh orangtua sebagai variabel bebas $(\mathrm{X})$ dan kedisiplinan siswa sebagai variabel terikat (Y). Variabel-variabel dalam penelitian dihubungkan pada satu kelompok responden, hubungan variabel yang ada dalam penelitian ini berbentuk bivariat, yaitu hubungan yang melibatkan satu variabel bebas dan satu variabel terikat (Kurniati, Nur, \& Andriani, 2020). Hubungan bivariat itu dapat digambarkan sebagai berikut :

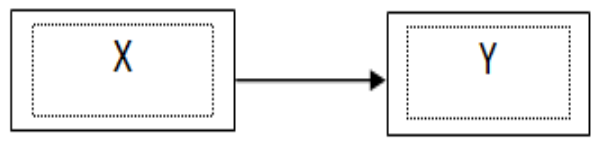

Keterangan :

$\mathrm{X}=$ Pola asuh orang tua

$\mathrm{Y}=$ Kedisiplinan siswa

Penelitian ini dilaksanakan di SMP Negeri

15 Kota Kupang. Populasi dalam penelitian ini adalah siswa SMP Negeri 15 Kota dan orang tua yang berjumlah 60 orang. Teknik pengambilan sampel yang digunakan adalah teknik sampling total, dengan jumlah sampel sebanyak 60 orang.

Secara garis besar penelitian ini dilaksanakan melalui dua tahap, yaitu: (1) Tahap Persiapan yaitu (a) Peneliti melakukan observasi untuk mengetahui keadaan lingkungan sekolah dan siswa; (b) Peneliti menyusun kisi-kisi instrumen kuesioner Peneliti menyusun instrumen kuesioner; (c) Peneliti mengkonsultasikan kepada kepala sekolah dan guru Bimbingan dan Konseling tentang keadaan siswa di masa pandemi covid-19; (2) Tahap Pelaksanaan yaitu (a) Peneliti membagikan kuesioner kepada peserta didik; (b) Peneliti menjelaskan petunjuk pengisian kuesioner kepada peserta didik; (c) Peneliti membimbing peserta didik dalam pengisian kuesioner.

Hipotesis dalam penelitian ini yaitu "ada pengaruh pola asuh orangtua terhadap kedisiplinan belajar siswa di SMP Negeri 15 
Kota Kupang di Masa Pandemi Covid-19." Setelah masih-masing data Pola Asuh Orangtua dan Kedisiplinan Belajar di rumah diperoleh, maka selanjutnya dilakukan analisis terhadap data-data tersebut. Penulis akan melakukan perhitungan untuk memperoleh hasil penerimaan atau penolakan hipotesis dengan menggunakan rumus korelasi product moment, adapun rumusan hipotesis sebagai berikut:

$\mathrm{Ha}$ : Ada pengaruh pola asuh orangtua terhadap kedisiplinan belajar siswa SMP Negeri 15 Kota Kupang di Masa Pandemi Covid-19.

Ho : Tidak Ada pengaruh pola asuh orangtua terhadap kedisiplinan belajar siswa SMP Negeri 15 Kota Kupang di Masa Pandemi Covid-19.

Untuk menguji validitas, penulis menggunakan rumus korelasi yang dikenal dengan rumus product moment, yaitu sebagai berikut:

$$
\begin{aligned}
& r_{x y}=\frac{\sum x y}{\sqrt{\left(\sum x^{2}\right)\left(y^{2}\right)}} \\
& \text { Keterangan: } \\
& r_{x y} \quad=\text { Angka Indeks Korelasi " } r \text { " product moment } \\
& \sum x y \quad=\text { Jumlah hasil perkalian antara } x \text { dan } y \\
& \sum x \quad=\text { Jumlah seluruh } x \\
& \sum y \quad=\text { Jumlah seluruh } y
\end{aligned}
$$

Sementara Reliabilitas dalam penelitian ini menggunakn alat ukur (angket) yang digunakan untuk memperoleh data mempunyai reliabilitas (ketetapan, keajegan atau adanya unsur konstan dalam angket tersebut, tidak mengalami perubahan jawaban apabila diuji kepada responden secara terus menerus). Untuk mencari reliabilitas menggunakan rumus SpearmanBrown, sebagai berikut:

$$
r_{11}=\frac{2 x r_{1} / 21 / 2}{\left(1+r_{1 / 21} / 2\right)}
$$

\section{Keterangan:}

\section{In : :Reliabilitas Instrumen \\ In/21/2 : $: x y$ yang disebutkan sebagai indeks korelasi antara dua belahan instrumen.}

Untuk menguji kebenaran dan kepalsuan apakah secara signifikan terdapat pengaruh pola asuh orangtua terhadap kedisiplinan siswa maka peneliti menggunakan statistik korelasi product moment.

Sementara untuk mengetahui tinggi rendahnya tingkat hubungan yang ada antara variabel $\mathrm{X}$ dengan variabel $\mathrm{Y}$, maka sebagai acuannya dipergunakan tabel interpretasi nilai sebagai berikut:

\begin{tabular}{|c|c|}
\hline Interval Koefisien & Tingkat Hubungan \\
\hline $0,00-0,199$ & Sangat \\
$0,20-0,399$ & Rendah \\
$0,40-0,599$ & Rendah \\
$0,60-0,799$ & Sedang \\
$0,80-1,00$ & Kuat \\
& Sangat Kuat \\
\hline
\end{tabular}

\section{HASIL DAN PEMBAHASAN}

Penelitian ini dilaksanakan di SMP Negeri 15 Kota Kupang selama 12 hari mulai dari Tanggal 24 Agustus sampai 4 September 2021. Hasil Wawancara dengan Kepala Sekolah (Yusak Olla, S.Pd.) dan Guru Bimbingan Konseling (Nur Ermy, S.Pd) menyatakan bahwa proses pembelajaran di SMP Negeri 15 Kota Kupang dilakukan secara Online dan juga Ofline (Tatap Muka secara terbatas) dengan tujuan untuk mencegah mata rantai penularan virus corona di sekolah dikeluarkan kebijakan pelaksanaan pendidikan di masa darurat penyebaran corona virus (COVID-19) oleh Menteri Pendidikan dan Kebudayaan melalui surat edaran pada tanggal 24 Maret 2020, tentang kebijakan belajar dari rumah (BDR). Hal ini mengandung arti bahwa orang tua sementara waktu menggantikan peran guru dalam mendampingi anak belajar di rumah. Dalam penelitian ini, peneliti melibatkan Guru, Siswa dan Orang tua sebagai informan. Proses pengambilan data diperoleh melalui kegiatan BDR yang melibatkan unsur Guru Mata Pelajaran Bimbingan Konseling, siswa dan orang tua.

\section{Hasil Angket Pola Asuh Orang Tua Siswa SMP Negeri 15 Kota Kupang (Variabel X) \\ Dari hasil angket sebagaimana terlihat pada} tabel 1, diperoleh jumlah nilai 5039 dengan skor tertinggi 97 dan skor terendah yaitu 73. Hasil perhitungan tersebut setelah dicocokkan dengan tabel 2, dapat diketahui bahwa pola asuh orang tua terdapat frekuensi terbanyak yaitu pada kelas interval 83-87 sebanyak 20 orang responden dengan persentase $33,33 \%$ dan frekuensi terendah pada kelas interval 93-97 sebanyak 3 responden dengan persentase $5 \%$ yaitu $4,56 \%$. 
Petrisia Anas Waluwandja, Sanhedri Boimau, Dixon E.M. Taek Bete

Jurnal Bimbingan dan Konseling Ar-Rahman

Volume 7, Nomor 2, Tahun 2021

e-ISSN 2477-6300

Lebih lanjut, berdasarkan uraian pada tabel 3, dapat diketahui bahwa pola asuh orang tua dalam kategori "cukup baik", yaitu berada pada interval nilai 81-85 dengan nilai 83, $98 \%$.

Tabel 1. Hasil Angket Pola Asuh Orang Tua

Resp.1

Resp 1

Resp. 2

Resp. 3

Resp. 4

Resp. 5

Resp. 6

Resp. 7

Resp. 8

Resp. 9

Resp. 10

Resp. 11

Resp. 12

Resp. 13

Resp. 14

Resp. 15

Resp. 16

Resp. 17

Resp. 18

Resp. 19

Resp. 20

Resp. 21

Nilai
97
77
82
86
73
94
86
89
85
83
73
92
89
80
86
84
83
86
86
75
89

97
77
82
86
73
94
86
89
85
83
73
92
89
80
86
84
83
86
86
75
89

$\begin{array}{cc}\text { Resp } & \text { Nilai X } \\ \text { Resp. 31 } & 78 \\ \text { Resp. 32 } & 82\end{array}$

82

Resp. $34 \quad 76$

Resp. $35 \quad 92$

Resp. $36 \quad 87$

Resp. $37 \quad 88$

Resp. $38 \quad 93$

Resp. $39 \quad 89$

Resp. $40 \quad 87$

Resp. $41 \quad 80$

Resp. $42 \quad 90$

Resp. $43 \quad 84$

Resp. $44 \quad 88$

Resp. $45 \quad 84$

Resp. $46 \quad 80$

Resp. $47 \quad 77$

Resp. $48 \quad 77$

Resp. $49 \quad 88$

Resp. $50 \quad 80$

Resp. $51 \quad 87$

\begin{tabular}{llll} 
Resp. 22 & 78 & Resp. 52 & 91 \\
Resp. 23 & 88 & Resp. 53 & 82 \\
Resp. 24 & 79 & Resp. 54 & 84 \\
Resp. 25 & 80 & Resp. 55 & 82 \\
Resp. 26 & 80 & Resp. 56 & 78 \\
Resp. 27 & 87 & Resp. 57 & 89 \\
Resp. 28 & 77 & Resp. 58 & 86 \\
Resp. 29 & 80 & Resp. 59 & 77 \\
Resp. 30 & 86 & Resp. 60 & 87 \\
\hline
\end{tabular}

Tabel 2. Distribusi Frekuensi Bergolong Pola Asuh Orang Tua

\begin{tabular}{ccc}
\hline Kelas Interval & Frekuensi & Prosentasi \\
\hline $73-77$ & 9 & $15 \%$ \\
$78-82$ & 15 & $25 \%$ \\
$83-87$ & 20 & $33,33 \%$ \\
$88-92$ & 13 & $21,66 \%$ \\
$93-97$ & 3 & $5 \%$ \\
\hline Jumlah & 60 & $100 \%$ \\
\hline
\end{tabular}

Tabel 3. Kualitas Variabel X (Pola asuh orang tua)

\begin{tabular}{rlll}
\hline \multirow{2}{*}{ Rata-Rata } & Interval & Kualitas & Kritera \\
\hline & 90 ke atas & Sangat baik & Cukup Baik \\
\cline { 2 - 3 } $\mathbf{8 3 , 9 8}$ & $\mathbf{8 1 - \mathbf { 8 5 }}$ & Baik & \\
\cline { 2 - 3 } & $77-80$ & Cukup Baik & Kurang Baik \\
\cline { 2 - 3 } & 76 ke Bawah & Sangat Kurang Baik \\
\hline
\end{tabular}

\section{Hasil Angket Tingkat Kedisiplinan Siswa SMP Negeri 15 Kota Kupang (Variabel Y)}

Dari hasil angket sebagaimana terlihat pada tabel 4, diperoleh jumlah nilai dengan skor tertinggi 95 dan skor terendah yaitu 70. Interval skor kedisiplinan siswa SMP Negeri 15 Kota Kupang adalah 8,34\%.

Berdasarkan hasil perhitungan interval pada tabel 5, dapat diketahui bahwa tingkat kedisiplinan siswa terdapat frekuensi terbanyak yaitu pada kelas interval 81-85 sebanyak 20 orang responden dengan persentase $33,33 \%$ dan frekuensi terendah pada kelas interval 70-75 sebanyak 0 responden dengan persentase $1 \%$ adalah 4,6. Berikutnya dari uraian pada tabel 6 , dapat diketahui bahwa tingkat kedisiplinan siswa dalam kategori "cukup baik", yaitu berada pada interval nilai 79-83 dengan nilai 82,11\%.

Tabel 4. Data Hasil Kedisiplian Siswa SMP Negeri 15 Kota Kupang

\begin{tabular}{lclc}
\hline Resp & Nilai Y & Resp & Nilai Y \\
\hline Resp. 1 & 91 & Resp. 31 & 83 \\
Resp. 2 & 76 & Resp. 32 & 84 \\
Resp. 3 & 72 & Resp. 33 & 88 \\
Resp. 4 & 76 & Resp. 34 & 75 \\
Resp. 5 & 79 & Resp. 35 & 83 \\
Resp. 6 & 95 & Resp. 36 & 70 \\
Resp. 7 & 77 & Resp. 37 & 84 \\
Resp. 8 & 80 & Resp. 38 & 79 \\
Resp. 9 & 80 & Resp. 39 & 82 \\
Resp. 10 & 78 & Resp. 40 & 90
\end{tabular}

Dipublikasikan Oleh : 
Petrisia Anas Waluwandja, Sanhedri Boimau, Dixon E.M. Taek Bete Jurnal Bimbingan dan Konseling Ar-Rahman

Volume 7, Nomor 2, Tahun 2021

e-ISSN 2477-6300

$\begin{array}{llll}\text { Resp. 11 } & 71 & \text { Resp. 41 } & 77 \\ \text { Resp. 12 } & 81 & \text { Resp. 42 } & 79 \\ \text { Resp. 13 } & 87 & \text { Resp. 43 } & 87 \\ \text { Resp. 14 } & 91 & \text { Resp. 44 } & 84 \\ \text { Resp. 15 } & 87 & \text { Resp. 45 } & 90 \\ \text { Resp. 16 } & 92 & \text { Resp. 46 } & 81 \\ \text { Resp. 17 } & 78 & \text { Resp. 47 } & 78 \\ \text { Resp. 18 } & 83 & \text { Resp. 48 } & 76 \\ \text { Resp. 19 } & 80 & \text { Resp. 49 } & 93 \\ \text { Resp. 20 } & 81 & \text { Resp. 50 } & 86 \\ \text { Resp. 21 } & 83 & \text { Resp. 51 } & 85\end{array}$

\begin{tabular}{llll} 
Resp. 22 & 85 & Resp. 52 & 85 \\
Resp. 23 & 75 & Resp. 53 & 83 \\
Resp. 24 & 77 & Resp. 54 & 82 \\
Resp. 25 & 85 & Resp. 55 & 75 \\
Resp. 26 & 79 & Resp. 56 & 82 \\
Resp. 27 & 94 & Resp. 57 & 79 \\
Resp. 28 & 80 & Resp. 58 & 85 \\
Resp. 29 & 78 & Resp. 59 & 84 \\
Resp. 30 & 90 & Resp. 60 & 77 \\
\hline
\end{tabular}

Tabel 5. Distribusi Frekuensi Bergolong Tingkat Kedisiplinan

\begin{tabular}{lll}
\hline Kelas Interval & Frekuensi & Prosentasi \\
\hline $70-75$ & 6 & $1 \%$ \\
$76-80$ & 20 & $33,33 \%$ \\
$81-85$ & 20 & $33,33 \%$ \\
$86-90$ & 8 & $13,33 \%$ \\
$91-95$ & 6 & $1 \%$ \\
\hline Jumlah & $\mathbf{6 0}$ & $\mathbf{1 0 0 \%}$ \\
\hline
\end{tabular}

Tabel 6. Kualitas Variabel Y (Tingkat Kedisiplinan Siswa)

\begin{tabular}{llll} 
Rata-Rata & Interval & Kualitas & Kriteria \\
\hline & 89 ke atas & Sangat Disiplin & \\
& $84-88$ & Disiplin & \\
$\mathbf{8 2 , 1 1}$ & $\mathbf{7 9 - 8 3}$ & Cukup Disiplin & Cukup Disiplin \\
& $75-78$ & Kurang Disiplin & \\
\hline
\end{tabular}

\section{Analisis Uji Hipotesis}

Apabila nilai $\mathrm{t}_{\text {hitung }}(\mathrm{t} \mathrm{h})$ yang diperoleh lebih besar atau sama dengan nilai $\mathrm{t}_{\text {tabel }}(\mathrm{t} \mathrm{t})$ maka hipotesis diterima, sehingga ada hubungan yang signifikan pola asuh orang tua dengan tingkat kedisiplinan siswa SMP Negeri 15 Kota Kupang. Sedangkan apabila nilai $t_{\text {hitung }}\left(t_{h}\right)$ yang diperoleh lebih kecil dari nilai $\mathrm{t}_{\text {tabel }}\left(t_{\mathrm{t}}\right)$ maka hipotesis ditolak, sehingga tidak ada hubungan yang signifikan antara pola asuh orang tua dengan tingkat kedisiplinan siswa SMP Negeri 15 Kota Kupang.

Besarnya hubungan pola asuh orag tua dengan dengan tingkat kedisiplinan siswa SMP Negeri 15 Kota Kupang, diperoleh nilai $\mathrm{r}_{\mathrm{xy}} 0,526$ masuk dalam kategori "cukup kuat" pada interval0,40-0,599 dilihat dari tabel 3.

Dengan hasil perhitungan di atas, dapat dilihat bahwa $r_{\text {hitung }}$ sebesar0,526 lebih besar dari $r_{\text {tabel }}$ sebasar 0,254. Dengan demikian menunjukkan bahwa korelasi tersebut signifikan pada taraf 5\% dan menunjukkan arah korelasi positif.
Selanjutnya untuk menyatakan besar kecilnya kontribusi variabel $\mathrm{X}$ terhadap variabel $\mathrm{Y}$ adalah 27,66 dibulatkan menjadi $28 \%$. Artinya, pola asuh orang tua (variabel $\mathrm{X})$ memberikan kontribusi terhadap tigkat kedisiplinan siswa (varabel Y) SMP Negeri 15 Kota Kupang sebesar $28 \%$ dan sisanya $72 \%$ ditentukan oleh variabel lain. Sementara signifikasi hubungan variabel $\mathrm{X}$ dengan $\mathrm{Y}$ adalah 58 .
Analisis Lanjut
Analisis lanjut yaitu analisis yang digunakan untuk menganalisis hipotesis yang terdapat dalam analisis pendahuluan dan analisis uji hipotesis. Berdasarkan perhitungan analisis uji hipotesis dapat diketahui bahwa nilai dknya 58. Untuk mengetahui jarak signifikansinya dapat diperoleh melalui tabel nilai distribusit, baik pada taraf signifikansi $5 \%$ maupun $1 \%$. Jika $t_{\text {hitung }} \geq t_{\text {tabel }}$ maka hipotesis diterima, dan jika $t_{\text {hitung }} \leq$ tabel maka hipotesis ditolak. Dengan memeriksa perhitungan $\mathrm{t}_{\text {tabel }}$ ternyata dk sebesar 58 tidak terdapat dalam 
Petrisia Anas Waluwandja, Sanhedri Boimau, Dixon E.M. Taek Bete

Jurnal Bimbingan dan Konseling Ar-Rahman

Volume 7, Nomor 2, Tahun 2021

e-ISSN 2477-6300

tabel, maka dipakai $\mathrm{dk}$ yang mendekati pada

angka 58 yaitu dk sebesar 60 .

Tabel 7. Tabel Bantu Mencari Koefisien Korelasi

\begin{tabular}{cccccc}
\hline NO & $\mathbf{X}$ & $\mathbf{Y}$ & $\mathbf{X 2}$ & $\mathbf{Y 2}$ & $\mathbf{X Y}$ \\
\hline 1 & 97 & 91 & 9409 & 8281 & 8827 \\
2 & 77 & 76 & 5929 & 7744 & 5852 \\
3 & 82 & 72 & 6724 & 5158 & 5904 \\
4 & 86 & 76 & 7396 & 5776 & 6536 \\
5 & 73 & 79 & 5329 & 6241 & 5767 \\
6 & 94 & 95 & 8836 & 9025 & 8930 \\
7 & 86 & 77 & 7396 & 5929 & 6622 \\
8 & 89 & 80 & 7921 & 6400 & 7120 \\
9 & 85 & 80 & 7225 & 6400 & 6800 \\
10 & 83 & 78 & 6889 & 6084 & 6474 \\
11 & 73 & 71 & 5329 & 5041 & 5183 \\
12 & 92 & 81 & 8464 & 6561 & 7452 \\
13 & 89 & 87 & 7921 & 7569 & 7743 \\
14 & 80 & 91 & 6400 & 8281 & 7280 \\
15 & 86 & 87 & 7396 & 7569 & 7482 \\
16 & 84 & 92 & 7056 & 8464 & 7728 \\
17 & 83 & 78 & 6889 & 6084 & 6474 \\
18 & 86 & 83 & 7396 & 6889 & 7138 \\
19 & 86 & 80 & 7396 & 6400 & 6880 \\
20 & 75 & 81 & 5625 & 6561 & 6075 \\
21 & 89 & 83 & 7921 & 6889 & 7387 \\
22 & 78 & 85 & 6084 & 7225 & 6630 \\
23 & 88 & 75 & 7744 & 5625 & 6600 \\
24 & 79 & 77 & 6241 & 5929 & 6083 \\
25 & 80 & 85 & 6400 & 7225 & 6800 \\
26 & 80 & 79 & 6400 & 6241 & 6320 \\
27 & 87 & 94 & 7569 & 8836 & 8178 \\
28 & 77 & 80 & 5929 & 6400 & 6160 \\
29 & 80 & 78 & 6400 & 6084 & 6240 \\
30 & 86 & 90 & 7396 & 8100 & 7740 \\
& & & & &
\end{tabular}

\begin{tabular}{|c|c|c|c|c|c|}
\hline 31 & 78 & 83 & 6084 & 6889 & 6474 \\
\hline 32 & 82 & 84 & 6724 & 7056 & 6888 \\
\hline 33 & 86 & 88 & 7396 & 7744 & 7568 \\
\hline 34 & 76 & 75 & 5776 & 5625 & 5700 \\
\hline 35 & 92 & 83 & 8464 & 6889 & 7636 \\
\hline 36 & 87 & 70 & 7569 & 4900 & 6090 \\
\hline 37 & 88 & 84 & 7744 & 7056 & 7392 \\
\hline 38 & 93 & 79 & 8649 & 6241 & 7347 \\
\hline 39 & 89 & 82 & 7921 & 6724 & 7298 \\
\hline 40 & 87 & 90 & 7569 & 8100 & 7830 \\
\hline 41 & 80 & 77 & 6400 & 5929 & 6160 \\
\hline 42 & 90 & 79 & 8100 & 6241 & 7110 \\
\hline 43 & 84 & 87 & 7056 & 7569 & 7308 \\
\hline 44 & 88 & 84 & 7744 & 7056 & 7392 \\
\hline 45 & 84 & 90 & 7056 & 8100 & 7560 \\
\hline 46 & 80 & 81 & 6400 & 6561 & 6480 \\
\hline 47 & 77 & 78 & 5929 & 6084 & 6006 \\
\hline 48 & 77 & 76 & 5929 & 5776 & 5852 \\
\hline 49 & 88 & 93 & 7744 & 8649 & 8184 \\
\hline 50 & 80 & 86 & 6400 & 7396 & 6880 \\
\hline 51 & 87 & 85 & 7569 & 7225 & 7395 \\
\hline 52 & 91 & 85 & 8281 & 7225 & 7735 \\
\hline 53 & 82 & 83 & 67224 & 6889 & 6806 \\
\hline 54 & 84 & 82 & 7056 & 67224 & 6888 \\
\hline 55 & 82 & 75 & 67224 & 5625 & 6150 \\
\hline 56 & 78 & 82 & 6084 & 67224 & 6396 \\
\hline 57 & 89 & 79 & 7921 & 6241 & 7031 \\
\hline 58 & 86 & 85 & 7396 & 7225 & 7310 \\
\hline 59 & 77 & 84 & 5929 & 7056 & 6468 \\
\hline 60 & 87 & 77 & 7569 & 5929 & 6699 \\
\hline & 5039 & 4927 & 545917 & 529459 & 414438 \\
\hline
\end{tabular}

Tabel 8. Hasil Uji Signifikasi

\begin{tabular}{llllll}
\hline Uji Hiptesis & & $\mathrm{t}_{\text {tabel }}$ & & \\
& $\mathrm{t}_{\text {hitung }}$ & $5 \%$ & $1 \%$ & Keterangan & Hipotesis \\
\hline Uji t & $\mathbf{4 , 7 1 0 0}$ & $\mathbf{1 , 6 7 1}$ & $\mathbf{2 , 3 9 0}$ & Signifikan & Diterima \\
\hline
\end{tabular}

Berdasarkan uji analisis di atas, diketahui bahwa naik pada taraf signifikansi 5\% maupun $1 \%$ menunjukkan thitung $\geq$ ttabel $(4,7100 \geq 1,671)$ dan $(4,7100 \geq 2,390)$ maka Ha diterima. Hal ini juga diperkuat dengan hasil wawancara dengan Kepala SMP Negeri 15 Kota Kupang serta pengamatan sekilas bahwa siswasiswi di SMP Negeri 15 Kota Kupang sudah 
tergolong cukup disiplin. Rata-rata siswa mengikuti proses pembelajaran tepat waktunya sekitar jam 07.00 Wita. Siswa juga aktif dalam mengikuti ekstrakulikuler disekolah seperti drumband dan pramuka. Dengan demikian, hipotesis yang peneliti ajukan yang berbunyi ada hubungan yang signifikan antara pola asuh orangtua dengan tingkat kedisiplinan siswa SMP Negeri 15 Kota Kupang dapat diterima kebenarannya.

\section{Pembahasan}

Hasil penelitian menunjukan ada hubungan antara pola asuh orang tua dengan kedisiplinan siswa SMP Negeri 15 Kota Kupang. Berdasarkan uraian tersebut dijelaskan bahwa pola asuh orang tua memiliki kontribusi terhadap kedisiplinan. Siswa yang mendapatkan pola asuh dari orang tua cenderung memiliki kedisiplinan yang tinggi.

Kedisiplinan dapat ditanamkan di lingkungan keluarga dengan pola asuh orang tua dan kedisiplinan juga dapat diterapkan pada sekolah SMP Negeri 15 Kota Kupang seperti disiplin belajar. Disiplin belajar siswa dapat diketahui dengan ciri-ciri yaitu masuk kelas sesuai jadwal yang ditetapkan, melakukan kegiatan di sekolah sesuai dengan petunjuk guru dan aturan sekolah, melaksanakan piket kelas sebelum kegiatan belajar dimulai, meminta izin jika berhalangan hadir mengikuti kegiatan belajar di sekolah, menyapa guru dan teman saat bertemu, dan mengikuti upacara setiap hari senin atau upacara hari nasional lainnya degan tertib (Kurniati, Nur, \& Andriani, 2020).

Hal tersebut sejalan dengan Octaviani yang menyatakan bahwa kedisiplinan merupakan locus education yaitu sarana siswa belajar moral agar menjadi manusia aktif di lingkungan sosial masyarakat. Kedisiplinan tersebut terlihat dari kehadiran siswa di sekolah. Jadi melalui kedisiplinan di sekolah, sikap kedisiplinan akan berlaku pada kehidupan bermasyarakat yang diterapkan siswa saat dewasa (Say, 2020).

Kedisiplinan juga dipengaruhi oleh sistem mikro (lingkungan terdekat, seperti keluarga), sistem meso (hubungan antara orang tua dengan guru), sistem exo (media elektonik dan non elektronik), Sistem makro terdiri dari ideologi negara, pemerintah, tradisi, agama, hukum, adat, dan budaya (Octaviani, 2020).

Dari konsep pendapat di atas, kedisiplinan perlu ditegakkan, jika kedisiplinan siswa sudah terbentuk dengan baik, maka kedisiplinan bisa menjadi karakter siswa.
Dalam kehidupan sehari-harikarakter kedisiplinan akan tetap melekat pada diri siswa.

Berdasarkan pendapat di atas, serta hasil penelitian menunjukkan bahwa pola asuh orang tua siswa kelas SMP Negeri 15 Kota Kupang dengan nilai rata-rata sebesar 83, 98 termasuk kedalam kategori "cukup baik" yaitu berada pada interval 81-85. Sedangkan tingkat kedisiplinan siswa kelas SMP Negeri 15 Kota Kupang dengan nilai rata-rata sebesar 82,11 dikategorikan "cukup baik" yaitu berada pada interval 78-83.

Hasil analisis hipotesis dengan menggunakan analisis korelasi product moment menunjukkan bahwa nilair ${ }_{x y}=0,526$ berada pada arah yang positif(Lilawati, 2020). Maka hubungan pola asuh orang tua dengan tingkat kedisiplinan siswa SMP Negeri 15 Kota Kupang termasuk dalam kategori "cukup kuat" dengan interval $0,40-0,599$.

Data penelitian juga menunjukkan bahwa $\mathrm{t}_{\text {hitung }}=0,526$, sedangkan $\mathrm{t}_{\text {tabel }}$ pada taraf signifikansi $5 \%=1,671$ dan t tabel pada taraf signifikan $1 \%=2,390$. Ini berarti bahwa $t_{\text {hitung }}$ lebih besar dari $t_{\text {tabel }}$. Maka dapat disimpulkan bahwa ada hubungan yang signifikan antara pola asuh orang tua dengan tingkat kedisiplinan siswa SMP Negeri 15 Kota Kupang.

\section{PENUTUP}

Hasil penelitian dan pembahasan menunjukkan bahwa : (1) Pola asuh orang tua siswa SMP Negeri 15 Kota Kupang dengan nilai rata-rata sebesar 83, 98 termasuk kedalam kategori "cukup baik" yaitu berada pada interval 81-85; (2) Tingkat kedisiplinan siswa SMP Negeri 15 Kota Kupang dengan nilai rata-rata sebesar 82,11 dikategorikan "cukup baik" yaitu berada pada interval 78-83; (3) Hasil analisis hipotesis dengan menggunakan analisis korelasi product moment menunjukkan bahwa nilairxy = 0,526 berada pada arah yang positif. Hubungan pola asuh orang tua dengan tingkat kedisiplinan siswa SMP Negeri 15 Kota Kupang termasuk dalam kategori "cukup kuat" dengan interval 0,40-0,599; (4) Data penelitian dan hasil juga menunjukkan bahwa thitung $=0,526$, sedangkan ttabel pada taraf signifikansi $5 \%=1,671$ dan $\mathrm{t}$ tabel pada taraf signifikan $1 \%=2,390$. Ini berarti bahwa thitung lebih besar dari ttabel. Maka dapat disimpulkan bahwa ada hubungan yang signifikan antara pola asuh orang tua dengan tingkat kedisiplinan siswa kelas SMP Negeri 15 Kota Kupang 
Petrisia Anas Waluwandja, Sanhedri Boimau, Dixon E.M. Taek Bete

Jurnal Bimbingan dan Konseling Ar-Rahman

Volume 7, Nomor 2, Tahun 2021

e-ISSN 2477-6300

Berdasarkan kesimpulan di atas maka, dapat disarankan hal-hal sebagai berikut : (1) Hendaknya Guru dan orangtua siswa pada SMP Negeri 15 Kota Kupang perlu meningkatkan pola asuh yang tepat sehingga dapat meningkatkan prsestasi belajar siswa; (2) Diharapkan peserta didik lebih aktif dan antusias dalam proses pembelajaran baik itu di rumah maupun di sekolah; (3) Peserta didik belajar untuk fokus dan mengontrol diri agar tercipta iklim yang kondusif selama pembelajaran, sehingga berimbas pada peningkatan prestasi; dan (4) Kedisiplinan dapat ditanamkan di lingkungan keluarga dengan pola asuh orang tua dan kedisiplinan juga dapat di terapkan di sekolah seperti disiplin belajar.

\section{REFERENSI}

Armico A, (2014. Psikologi Perkembangan, (Jakarta: PT. RINEKA CIPTA.

Djamarah Syaiful, (2014). Pola Asuh Orang Tua dan Komunikasi dalam Keluarga, (Jakarta: Rineka Cipta).

Fuad Ihsan, (2016). Pendidikan dalam Keluarga, Jakarta: Bulan Bintang.

Fransisco, D. (2014). Educational Psychology, (San Fransisco): Wadsworth Publishing.

Gibson J.T. (2011). Growing Up A Study Of Children. Wadsworth Publishing.

Handayani, E. S., \& Subakti, H. (2020). Pengaruh Disiplin Belajar terhadap Hasil Belajar Bahasa Indonesia di Sekolah Dasar. Jurnal Basicedu, 5(1), 151-164. https://doi.org/10.31004/basicedu.v5i1.63 $\underline{3}$

Hapsari Titi Estima, dkk. (2019). Pola Asuh Orang Tua Dalam Menerapkan Kedisiplinan Siswa Kelas IV Di SD Negeri Lobang 01 Batang. Jurnal Basicedu Volume 3 Nomor 3 Halaman 870-873.

Hasan Basri, (2012). Keluarga Sakinah, (Yogjakarta: Pustaka Pelajar)

Herliandry, Devi ., N. M. E. S. H. K. (2020). Pembelajaran Pada Masa Pandemi Covid19. Jurnal Pendidikan Teknologi, 22(1), 65-69. https://doi.org/10.21009/jtp.v22i1.15286

Kurniati, E., Nur Alfaeni, D. K., \& Andriani, F. (2020). Analisis Peran Orang Tua dalam Mendampingi Anak di Masa Pandemi Covid-19. Jurnal Obsesi : Jurnal Pendidikan Anak Usia Dini, 5(1), 241. https://doi.org/10.31004/obsesi.v5i1.541

Latipah Eva, (2012). Pengantar Psikologi Pendidikan, (Yogyakarta: Pedagogia)
Lilawati, A. (2020). Peran Orang Tua dalam Mendukung Kegiatan Pembelajaran di Rumah pada Masa Pandemi. Jurnal Obsesi : Jurnal Pendidikan Anak Usia Dini, $\quad 5 \quad$ (1), 549. https://doi.org/10.31004/obsesi.v5i1.630

Mayasari Dian, Kamaruddin dan Shiong Siau. (2021). Korelasi Antara Pola Asuh Orang Tua Dengan Kedisiplinan Belajar Siswa Kelas XI Di SMK Mudita Singkawang. JOURNAL OF EDUCATIONAL REVIEW AND RESEARCH Vol. 4 No. 1, July 2021. Page: $1-5$. EISSN: 2597-9760, P-ISSN: 2597-9752.

Musaheri, (2013). Pengantar Pendidikan, Yogyakarta: IRCiSoD.

Octaviani, (2020). Pengaruh Pola Asuh Orang Tua dan Disiplin Belajar Terhadap Hasil Belajar PPKn Siswa Kelas V SDN Dabin I Kecamatan Tegal Selatan Kota Tegal.

Prijodarminto Soegeng, (2015). Disiplin Kiat Menuju Sukses, (Jakarta: Pradnya Paramita)

Say, S. (2020). Pengaruh Pola Asuh Orang Tua Dan Disiplin Belajar Terhadap Prestasi Belajar Siswa. Jurnal Pendidikan Dan Bimbingan Konseling, 1(1), 1-6.

Shochib, M. (2014). Pola Asuh Orang Tua dalam Membantu Anak Mengembangkan Disiplin Diri. Jakarta: Rineka Cipta.

Srinam S. Khalsa. (2015). Metode Pengajaran Disiplin \& Harga Diri: Strategi, Anekdot,dan Pelajaran Efektif Untuk Keberhasilan Manajemen Kelas Jakarta: PT Indeks

Syamsu Yusuf LN, (2013). Psikologi Perkembangan Anak dan Remaja, (Bandung: Remaja Rosda Karya.

Wiyani, N. A. (2013). (2013). Bina Karakter Anak Usia Dini. Yogyakarta Arruzz Media. 